\title{
ファイバーモデルと陽的時間積分法を用いたR Cラーメン構造の地震応答解析
}

Seismic Response Analysis of RC Rahmen Structures using Fiber Model and Explicit Time Integration Scheme

\author{
松浦幹佳*，小林治俊**，園田恵一郎*** \\ Mikiyoshi MATSUURA, Harutoshi KOBAYASHI and Keiichiro SONODA
}
*正会員 工修 大阪市立大学大学院後期博士課程［(株）松浦建設］（广558-8585 大阪市住吉区杉本3-3-138）
**正会員 工博 大阪市立大学助教授 工学部土木工学科（テ558-8585 大阪市住吉区杉本 3-3-138）
***フェロー 工博 大阪市立大学大学教授 工学部土木工学科（テ558-8585 大阪市住吉区杉本3-3-138）

\begin{abstract}
This paper is devoted to develop a numerical method using fiber model and explicit time integration scheme for the seismic response analysis of RC rahmen structures. The fiber model is applied to acquire the sectional forcedeformation relations. $\mathrm{RC}$ cross sections are divided into multi-layers of concrete and steel bar. Nonlinear properties of steel bar and concrete are introduced between adjacent rigid elements. Numerical calculations for a RC Rahmen structure are carried out under the observed ground accelerations at Hyogoken Nanbu Earthquake (Kobe, 1995), and nonlinear dynamic properties of deformation and resultant force are discussed in detail.
\end{abstract}

Key Words : seismic response analysis, fiber model, explicit time integration scheme

\section{1. まえがき}

1995 年 1 月 17 日に発生した兵庫県南部地震は, 高架 橋の橋脚をはじめとする RC 構造物に構造体としての致 命的損傷を与え，その中のいくつかは崩壊に至った．地 震後, 各分野での精力的な調査・研究が行われ，震災の 経験が土木構造物の設計書, 示方書に反映するよう努力 されている. 平成 8 年 12 月に改訂された道路橋示方書 の耐震設計編 1) では, 内陸直下型の地震に対し設計地 震動（レベル 2) は従来より大幅に増加した. 一方では, 単柱橋脚やラーメン橋脚など比較的簡単な形状のものに 対しては水平保有耐力の照査, ならびに複雑な地震応答 が予測される構造の場合には動的非線形応答解析を義務 づけている. すなわち, 現実の橋脚は不等脚のラーメン 形式や多径間ラーメン形式なども多く, 平成 8 年 12 月 の示方書の改訂によって動的非線形地震応答解析の必要 性が益々増してきたものと考えられる.

$\mathrm{RC}$ 構造物の動的非線形解析のソフトはすでにいくつ か開発されており，実施設計に利用されている，それら は，(1)連続体力学に基づく有限要素解析法，(2)骨組理 論に基づく変位解析法に大別される. 前者は理論的には 優れているが，弾塑性非線形解析では，計算量が膨大に なり, 小規模の橋脚に対しては経済性の面で問題もある. 一方後者は, 前者に比べて計算量は飛躍的に軽減される が, 既存のソフトでは, 部材の曲率と曲げモーメント関 係を入力值とした解析法が主流である. この曲率と曲げ モーメントの関係を求める手法として, 従来から Bernoulli の仮定，いわゆる平面保持の仮定に基づいた断 面分割法2）やファイバーモデル3）を用いた方法が行わ
れている. しかしながら， RC ラーメン構造物では部材 断面において曲げモーメントと軸力が連成するので曲げ モーメントや軸力のみの独立した関係を構成則として用 いることは不十分であると思われる.

平成 8 年 12 月の道路橋示方書の改訂では, コンクリ 一トの応力ーひずみ関係は拘束鉄筋の影響により変化さ せており, RC 部材の横拘束鉄筋内部のコンクリートは 拘束度に応じてより大きな限界ひずみを許容する曲線を 規定している. したがって，骨組解析法においても，多 様な応力ーひずみ曲線を採用し，同時に軸力およびせん 断力の影響も考慮できる解析手法が求められるようにな ってきた.

本研究はファイバーモデルと陽的時間積分法を用い て上記の要求を満足させる動的非線形解析法の開発をめ ざしたものである. 通常のラーメン構造では，柱または はり部材の端部に塑性ヒンジが発生し, 大地震時のラー メン全体の変形は塑性ヒンジの回転量に大きく支配され るので, 塑性ヒンジでの曲げと軸力の影響をできるだけ 正確に取り入れることに力点を置き，部材中間部の弾性 変形が支配する部分は比較的簡単に取り扱う方法を採用 した. すなわち，断面の構成則については平面保持の仮 定とファイバーモデルによる積分によって求め, 運動方 程式の時間積分は陽解法を用いた。 このような方法は剛 体バネモデル4）と類似しているが，陽解法を用いるた めに，バネという概念は導入せずに，断面の曲率と伸び という変形量から曲げモーメントと軸力という力への変 換則のみ考慮することにより, 非線形問題も線形問題と 同程度簡単に取り扱える点に大きな特徵がある.もちろ ん, 解の精度は要素分割に大きく影響されるが，部材端 
部では道路橋示方書で定義された塑性ヒンジ長に即した 要素分割を用い，部材中間部では比較的荒い分割を用い ることが合理的と思われる.

本論文では RC ラーメン橋脚を一つの解析対象とした 方法 5）を RC 断面構成および応力一ひずみ関係につい てさらに発展させ，実物により忠実なモデルの表現を試 みた. 最初に，提案する解法の定式化について述べ，つ いで兵庫県南部地震での観測地震波を用いた動的非線形 解析を行い，変形特性，断面力および応力履歴など調べ た。

\section{2. 解析手法}

\section{1 要素モデル}

本解析においては, ラーメン部材を骨格線に沿って要素 長 $d s$ で等分割する. 分割された剛体要素のうちの隣接 する 2 要素を図一1 のように要素 $\mathrm{i}$ および $\mathrm{j}$ とする. い ま各要素の $x, y$ 軸方向の変位をそれぞれ $u, v$ とし，さ らに $z$ 軸まわりの回転を $\theta$ として定義する. 要素端部で の骨格線方向ひずみ $\delta_{i j}$, 曲率 $\kappa_{i j}$, 骨格線直角方向ひ

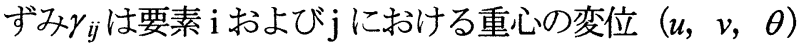
から求められ, 重心 $G_{i}$ および $G_{j}$ におけるひずみの平均 值として式（1）のようになる.

$$
\begin{aligned}
& \delta_{i j}=\left(u_{j}-u_{i}\right) / d s \\
& \gamma_{i j}=-\left(v_{j}-v_{i}\right) / d s+\left(\theta_{j}+\theta_{i}\right) / 2 \\
& \kappa_{i j}=\left(\theta_{j}-\theta_{i}\right) / d s
\end{aligned}
$$

各要素の重心から $d s / 2$ における要素端部に作用する断 面力は軸力 $N_{i j}$, 曲げモーメント $M_{i j}$, せん断力 $S_{i j}$ と し，座標軸の正負と一致するように与える. 本解析では 断面力の正負を次のように定義する. すなわち軸力は引 張状態を，曲げモーメントはラーメン骨格線内側に凸の 曲率を有する状態を, せん断力は部材軸と断面の外向き 法線ベクトルが一致する断面で座標系のベクトル成分と なるものをそれぞれ正方向とする. これらの断面力はひ ずみの関数として式 (2) のように表現でき, 関数 $f_{N}$, $f_{S}, f_{M}$ はコンクリートのひび割れ後は非線形となる.

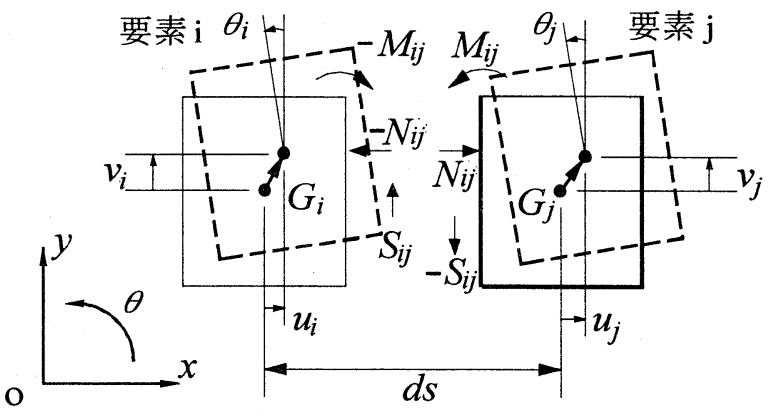

図-1 要素間の力の伝達

$$
\begin{aligned}
N_{i j} & =f_{N}\left(\delta_{i j}, \kappa_{i j}, \gamma_{i j}\right) \\
S_{i j} & =f_{S}\left(\delta_{i j}, \kappa_{i j}, \gamma_{i j}\right) \\
M_{i j} & =f_{M}\left(\delta_{i j}, \kappa_{i j}, \gamma_{i j}\right)
\end{aligned}
$$

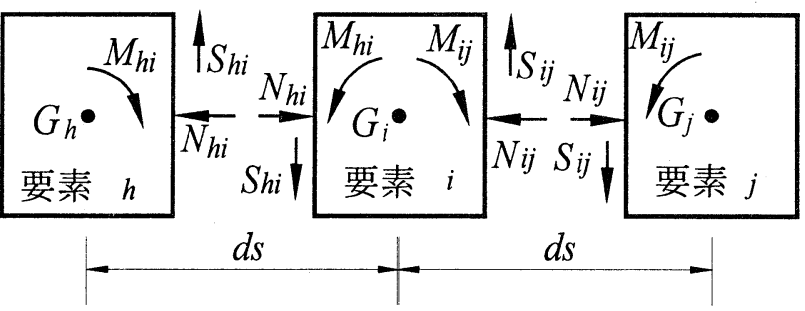

図-2 各要素に作用力する断面力

図一2 の要素 i に作用する力は座標軸方向について表 すと式（3）となる.

$$
\begin{aligned}
& X_{i}=N_{h i}-N_{i j} \\
& Y_{i}=-S_{h i}+S_{i j} \\
& M_{i}=M_{h i}-M_{i j}+\left(S_{h i}+S_{i j}\right) d s / 2
\end{aligned}
$$

また本解析法においてはフーチングおよび地盤バネも考 慮できるが本研究ではこれらを考慮していない.

\section{2 ファイバーモデル}

RC 部材においては軸力と曲げモーメントは互いに連 成する. そこで RC 部材の非線形特性を表現するために 本解析では軸力と曲げモーメントがそれぞれ連成するモ デルを考える. RC 断面は図一-3 のようにコンクリート 要素と鉄筋要素から構成され, 鉄筋の付着は完全に維持 するとした上で Bernoulli の仮定（平面保持の仮定）を 適用する. $A_{s}$ および $A_{s}^{\prime}$ はそれぞれ主鉄筋の断面積, $A_{s}^{\prime \prime}$ は左右側面鉄筋の断面積の合計である. 断面内の外 縁から $\zeta_{i}$ の位置に於けるコンクリートひずみ $\varepsilon_{c i}$, 側面 鉄筋ひずみ $\varepsilon_{s i}$ および主鉄筋ひずみ $\varepsilon_{s}^{\prime} ， \varepsilon_{s}$ は式 (4) と なる.

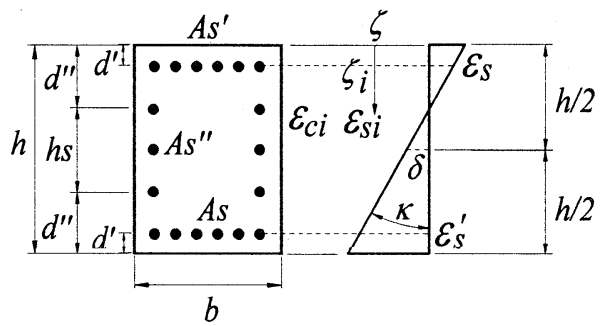
(a) RC 断面
(b)ひずみ分布

図-3 平面保持の仮定に基づく RC 断面内のひずみ

$$
\begin{array}{ll}
\varepsilon_{c i}=\delta+\left(\zeta_{i}-h / 2\right) \kappa, & \varepsilon_{s i}=\delta+\left(\zeta_{i}-h / 2\right) \kappa \\
\varepsilon_{s}=\delta+\left(h / 2-d^{\prime}\right) \kappa, & \varepsilon_{s}^{\prime}=\delta-\left(h / 2-d^{\prime}\right) \kappa
\end{array}
$$


ここで $\delta$ および $\kappa$ は式（1）において求められた要素 端部でのひずみであり，コンクリートおよび鉄筋のひず みはすべて引張状態を正としている.

\section{3 応力一ひずみ関係}

式 (4) によって求められるコンクリートおよび鉄筋 のひずみに対して図ー4 および 5 の応力一ひずみ関係を 適用する. ここで, 図一 4 におけるコンクリート圧縮時 の応力一ひずみ関係式は次のタイプ II の地震動による 動的解析で用いられるもので式（5）として道路橋示方 書に規定されている.

$$
\begin{gathered}
\sigma_{c}=\left\{\begin{array}{c}
E_{c} \mathcal{E}_{c}\left[1-(1 / n)\left(\varepsilon_{c} / \varepsilon_{c c}\right)^{n-1}\right] \\
\left(-\varepsilon_{c c} \leq-\varepsilon_{c} \leq 0\right) \\
\sigma_{c c}-E_{d e s}\left(\varepsilon_{c}-\varepsilon_{c c}\right) \\
\left(-\varepsilon_{c u} \leq-\varepsilon_{c} \leq-\varepsilon_{c c}\right)
\end{array}\right. \\
n=E_{c} \varepsilon_{c c} /\left(E_{c} \mathcal{E}_{c c}-\sigma_{c c}\right)
\end{gathered}
$$

しかし除荷曲線および引張特性については特に規定され ていない，そこで本研究において圧縮時の除荷勾配には 初期勾配 $E_{c}$ を用いた. また式（5）は横拘束笳による拘 束効果を評価したものであるので，主筋および側面鉄筋 内部のコンクリートについては終局ひずみとして $-\varepsilon_{c u}$ を適用し，解析終了とした. ただし主鉄筋および側面鉄 筋外部のかぶりコンクリートについては - $\varepsilon_{c c}$ において 圧壊し, 応力を解放するがその後も解析を続行した. $E_{c}$ および $E_{\text {des }}$ はそれぞれコンクリートの初期弾性係数およ び軟化時の弾性倸数である.

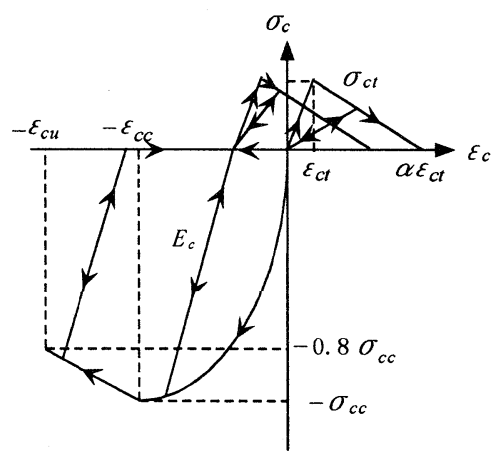

図ー4 コンクリートの応力一ひずみ関係

一方，引張領域においても引張ひずみ $\alpha \varepsilon_{c t}$ まで軟化 特性を考慮した. 式（6）は解析モデルの破壊エネルギ ニ $G_{f}$ および引張応力による仕事量の関係を示したもの であり，軟化保数 $\alpha$ は式（7）によって与えた．既往 の研究6) によると RC断面の破壊エネルギー $G_{f}$ は式 (8) で与えられ, 本研究では $G_{f}=300 \sigma_{c t}{ }^{2} / E_{c}$ とした. 引張軟 化領域における除荷は原点を指向するものとし残留ひず み発生時はを残留ひずみ量を指向するものとした.

$$
\begin{gathered}
\overline{G_{f}}=(d s / S) G_{f}=(1 / 2) \sigma_{c t} \alpha \varepsilon_{c t} S \\
\alpha=\frac{2 G_{f} d s}{\sigma_{c t} \varepsilon_{c t} S^{2}} \\
G_{f}=200 \sim 400 f_{c t}^{2} / E_{c} \quad(\mathrm{~N} / \mathrm{mm})
\end{gathered}
$$

なお，式 (6)，(7) において $S$ はせん断補強筋間隔， $d s$ はモデル重心間距離である.

主鉄筋および側面鉄筋の応力一ひずみ構成関係は図 -5 のようにバイリニア型とし除荷過程勾配は初期勾配 $E_{s}$ と同じとした.

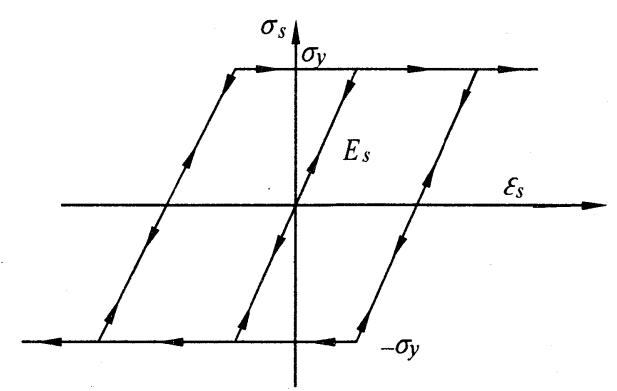

図-5 鉄筋の応力一ひずみ関係

\section{4 断面力}

前項の構成関係から求めたコンクリートおよび鉄筋の 応力を積分し軸力および曲げモーメントを算出する. 式

（2）の断面力は平面保持の仮定を適用し，コンクリー トおよび鉄筋の構成関係から次の式（9）によって与え られる。

$$
\begin{aligned}
N= & b \int_{0}^{h} \sigma c i d \zeta+b s \int_{d^{\prime \prime}}^{h-d_{s i}^{\prime \prime}} d \zeta+\sigma_{s} A s+\sigma_{s^{\prime}} A s^{\prime} \\
M & =b \int_{0}^{h} \sigma c i(\zeta-h / 2) d \zeta+b s \int_{d^{\prime \prime}}^{h-d^{\prime \prime}}(\zeta-h s / 2) d \zeta \\
& -\sigma_{s} A s\left(h / 2-d^{\prime}\right)+\sigma_{s^{\prime}} A s^{\prime}\left(h / 2-d^{\prime}\right) \\
S & =G_{c} h b \gamma
\end{aligned}
$$

上式で $\sigma_{c i} ， \sigma_{s i} ， \sigma_{s}$ およで $\sigma_{s}^{\prime}$ は図一个におけるひずみ $\varepsilon_{c i}, \varepsilon_{s i}, \varepsilon_{s}$ および $\varepsilon_{s}^{\prime}$ にそれぞれ対応する応力であ る. また，側面鉄筋は取り扱いを簡略化するために断面 積 $A_{s}^{\prime \prime}$ が断面深さ $\zeta$ 方向に長さ $h_{s}$, 幅 $b_{s}$ で分布してい るとした. 式 (9) における積分はシンプソンの積分公 式によって数值積分を行い，せん断力はせん断弾性係数 $G_{c}$ を用いて完全弾性として取り扱った.

\section{5 陽解法による時間積分}

全要素の時刻 $t$ における変位, 速度および加速度をそ れぞれ ${ }^{t} \mathbf{U},{ }^{t} \dot{\mathbf{U}}$ および ${ }^{t} \dot{\mathbf{U}}$ とするとき, 時刻 $t$ における 運動方程式を式（10）に示す.

$$
\mathbf{M}^{t} \ddot{\mathbf{U}}+\mathbf{C}^{t} \dot{\mathbf{U}}+{ }^{t} \mathbf{F} i={ }^{t} \mathbf{F} e-\mathbf{M}\left({ }^{t} \ddot{z} \mathbf{I}\right)
$$


式（10）を変形し，

$$
\begin{aligned}
& \mathbf{M}^{t} \ddot{\mathbf{U}}={ }^{t} \mathbf{R} \\
& { }^{t} \mathbf{R}={ }^{t} \mathbf{F}_{e}-{ }^{t} \mathbf{F}_{i}-\mathbf{M}\left({ }^{t} \ddot{z} \mathbf{I}\right)-\mathbf{C}^{t} \dot{\mathbf{U}}
\end{aligned}
$$

ここに $\mathbf{M}$ : 各要素の質量および慣性モーメントからな るマトリックス, $\mathbf{C}$ : 減衰定数, ${ }^{t} \mathbf{F}_{i}$ : 式 (9) の断面力 を式（3）に代入して得られる力（静的不釣合い力）の ベクトル, ${ }^{t} \mathbf{F}_{e}$ : 自重等の初期荷重ベクトル, ${ }^{t} \ddot{z}:$ : 地震 入力加速度, I : 地震力の方向ベクトル. 各要素の加速 度 ${ }^{\prime} \dot{\mathbf{U}}$ は陽的積分法の 1 つである中心差分法を用いると 時刻 $t+\Delta t$ における剛体要素の変位 ${ }^{t+}{ }^{t} \mathbf{U}$ は式（11）に 示すように時刻 $t, t-\Delta t$ の状態量で与えられる.

$$
{ }^{t+\Delta t} \mathbf{U}=\Delta t^{2} \mathbf{M}^{-1}{ }^{t} \mathbf{R}+2{ }^{t} \mathbf{U}-{ }^{t-\Delta t} \mathbf{U}
$$

ここに $\Delta t$ は時間刻みであり, 差分式が発散せずに安定 解を得るための条件が $t_{\text {min }}$ を解析モデルの最小固有周期 とすると $\Delta t<t_{\min } / \pi$ であることから，本解析においては $t_{\text {min }}$ の $1 / 10$ を時間刻み $\Delta t$ とした. なお後の解析例では $\Delta t$ $=113 \mu \mathrm{s}$ とした. 解析のフローチャートを図一6に示寸.

\section{3. 数值解析}

\section{1 解析モデル}

本解析で使用した R C 橋脚モデルを図-7 に示す。こ れは II 種地盤におけるタイプ II の地震動を想定し，地 震時保有水平耐力法によって設計されたものである. た だしハンチおよび張出部は省略している．橋脚は隅角部 を剛域として隅角部を除く柱およびはり部材をそれぞれ 骨格線にそって11 分割している.この分割数は式 (12) に示す道路橋示方書の塑性ヒンジ長 $L_{p}$ に分割長が相当 するよう配慮したものである.

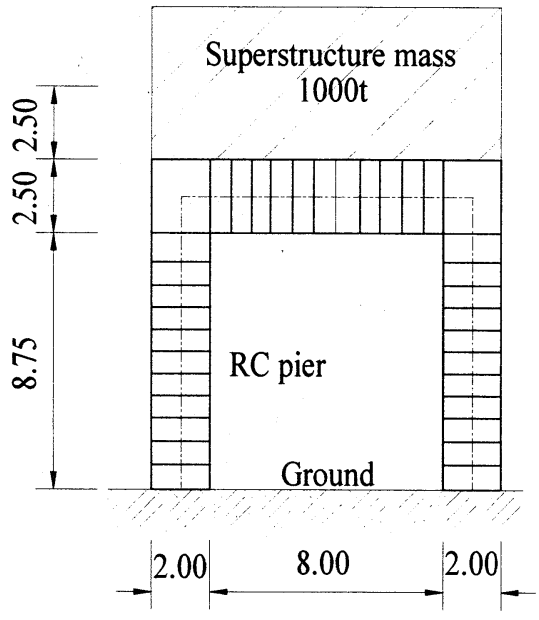

図-7 解析モデル (単位: $\mathrm{m}$ )

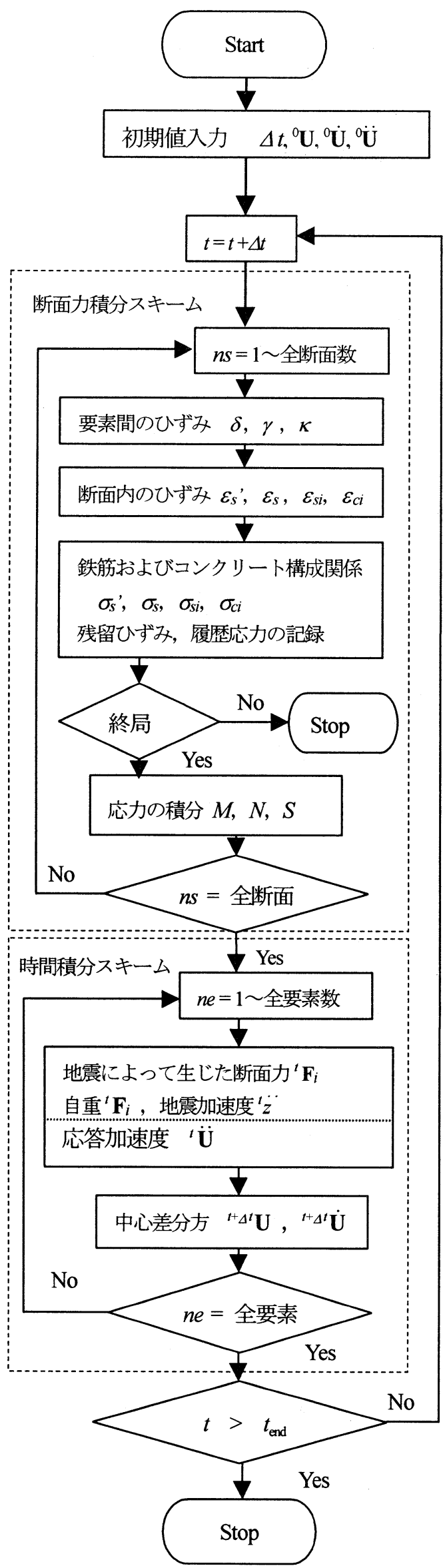

図ー6 解析フローチャート 


$$
L_{p}=0.2 H-0.1 h \quad\left(0.1 h \leq L_{p} \leq 0.5 h\right)
$$

ただし, $H(\mathrm{~m})$ は橋脚基部からはり軸線までの高さの $1 / 2$, $h(\mathrm{~m})$ は断面高さである.

隅角部は終局状態においても剛域としており，本解析 では塑性ヒンジが，はり両端および柱上下端において発 生する可能性がある. この RC橋脚は質量 $1000 \mathrm{t}$ の上部 工を有しており, 重心は橋脚天端から $2.5 \mathrm{~m}$ 上方に位置 している. 本解析においては，この上部工質量をはり部 材に付加質量として与えた。 また橋脚および上部工の自 重も考慮している. 地震加速度は各剛体要素に直接与兄 るため，変位は地盤に対する相対変位として出力する. 解析に用いた材料等の諸元を表一 1 に示寸.

表 -1 解析諸元

\begin{tabular}{|c|c|c|c|}
\hline 項 & 記 号 & 単 位 & 数 \\
\hline 橋脚奥行き & $b$ & $\mathrm{~m}$ & 2.7 \\
\hline 減衰定数 & & $\%$ & 5 \\
\hline \multicolumn{4}{|l|}{ コンクリート } \\
\hline 設計基準強度 & $\sigma_{c k}$ & $\mathrm{~N} / \mathrm{mm}^{2}$ & 23.5 \\
\hline 弾性係数 & $E_{c}$ & $\mathrm{~N} / \mathrm{mm}^{2}$ & $2.45 \times 10^{4}$ \\
\hline \multicolumn{4}{|l|}{ 鉄筋 } \\
\hline 降伏強度 & $\sigma_{y}$ & $\mathrm{~N} / \mathrm{mm}^{2}$ & 343 \\
\hline 弾性係数 & $E_{s}$ & $\mathrm{~N} / \mathrm{mm}^{2}$ & $2.05 \times 10^{5}$ \\
\hline \multicolumn{4}{|l|}{ 柱部材 } \\
\hline 柱断面高さ & $h$ & $\mathrm{~m}$ & 2.0 \\
\hline 主筋鉄筋量 & $A_{s}, A_{s}^{\prime}$ & $\mathrm{cm}^{2}$ & 166.7 \\
\hline 主筋かぶり & $d^{\prime}$ & $\mathrm{cm}$ & 13 \\
\hline 側面鉄筋 & $A_{s}{ }^{\prime \prime}$ & $\mathrm{cm}^{2}$ & 412.9 \\
\hline 側面鉄筋かぶり & $d^{\prime \prime}$ & $\mathrm{cm}$ & 45 \\
\hline せん断筋鉄筋量 & $A_{w}$ & $\mathrm{~cm}^{2}$ & 19.3 \\
\hline せん断筋間隔 & $S$ & $\mathrm{~cm}$ & 15 \\
\hline \multicolumn{4}{|l|}{ はり部材 } \\
\hline はり断面高さ & $h$ & $\mathrm{~m}$ & 2.5 \\
\hline 主筋上鉄筋量 & $A_{s}^{\prime}$ & $\mathrm{cm}^{2}$ & 162.1 \\
\hline 主筋下鉄筋量 & $A_{s}$ & $\mathrm{~cm}^{2}$ & 212.8 \\
\hline 主筋かぶり & $d^{\prime}$ & $\mathrm{cm}$ & 13 \\
\hline 側面鉄筋 & $A_{s} "$ & $\mathrm{~cm}^{2}$ & 34.4 \\
\hline 側面鉄筋かぶり & $d^{\prime \prime}$ & $\mathrm{cm}$ & 45 \\
\hline せん断筋鉄筋量 & $A_{w}$ & $\mathrm{~cm}^{2}$ & 19.3 \\
\hline せん断筋間隔 & $S$ & $\mathrm{~cm}$ & 15 \\
\hline
\end{tabular}

\section{2 入力地震動}

入力地震動として兵庫県南部地震で観測された 2 種類 の加速度データを使用した. 図一8 (a)および(b)はそれぞ れ神戸海洋気象台および JR 鷹取駅での観測地震波形で 特に振幅の大きかった時刻を中心とする 20 秒間の観測 波形である. 神戸海洋気象台波形は I 種地盤として，JR
鷹取駅波形はII 種地盤の地震波形として使用している. 神戸海洋気象台波形の方が JR 鷹取駅波形と比較し短周 期成分が卓越している. 本解析では比較検討のため II 種地盤として設計された解析モデルに I 種地盤の神戸海 洋気象台波形を入力波形として用い水平变位応答, 断面 力応答および履歴を比較検討した. さらに初期軸力の $\mathrm{RC}$ ラーメン構造に与える影響を調べるために初期軸力 $N=$ -7.0 MN を無視した場合の解析も行った. 3 タイプの 解析ケースを表-2 に示寸，なお，減衰マトリックスは 質量マトリックスに比例する係数として 1 次モードに対 する $5 \%$ の減衰定数に相当するものを用いた.

表一2 解析ケース

\begin{tabular}{|l|l|c|}
\hline & \multicolumn{1}{|c|}{ 入力地震波 } & 初期軸力の有無 \\
\hline ケース (a) & 神戸海洋気象台 & 有 \\
\hline ケース (b) & J R鷹取駅 & 有 \\
\hline ケース (c) & 神戸海洋気象台 & 無 \\
\hline
\end{tabular}

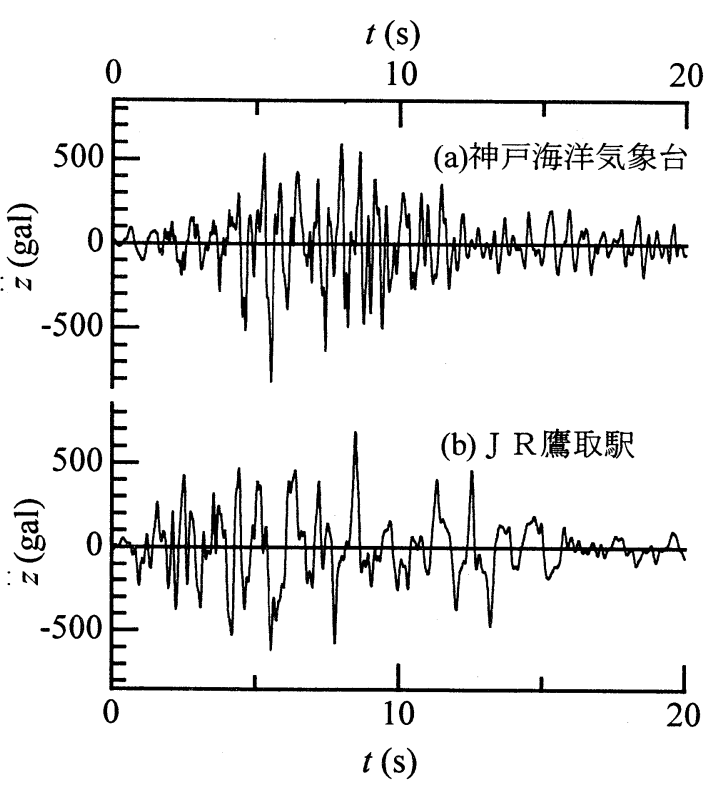

図-8 地震加速度

\section{3 水平変位応答}

隅角部の水平変位応答を図-9 に示す．ケース(a)では 最大変位約 $75 \mathrm{~mm}$ であるのに対しケース(b)は約 $60 \mathrm{~mm}$ となっている. また残留変位は前者が約 $30 \mathrm{~mm}$ である のに対し後者は殆じ発生していない.このケース(a)の 残留変位は神戸海洋気象台加速度波形の時刻 $t=5 \mathrm{~s}$ 頃の 最大加速度約 $800 \mathrm{gal}$ を受けて発生している.すなわち, $\mathrm{RC}$ ラーメン構造の残留変位は入力加速度のピーク值に 敏感に影響を受けていると思われる，またケース(c)は 初期軸力を考慮した場合のケース(a)と比較してより大 きな残留変位約 $80 \mathrm{~mm}$ が発生している.このことから 初期軸力は RC ラーメン構造の応答に大きく影響するこ とがわかる. ケース(a)〜 (c)いずれのケースにおいて もかぶりコンクリートは圧壊したものの横拘束筋内部の 
コンクリートは圧壊（終局状態）に至らなかった. 一方, 数值計算過程おいて発散現象は生じることなくいずれの ケースも安定した計算結果が得られた.

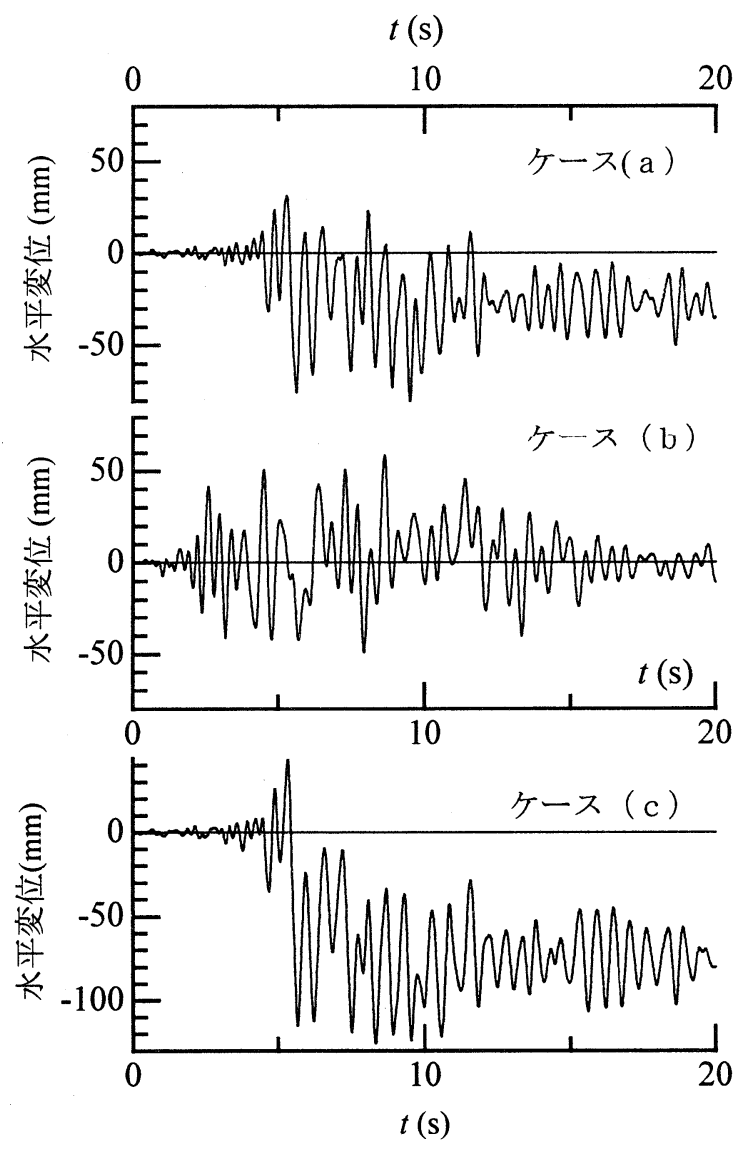

図-9 水平変位応答

\section{4 断面力応答}

図一10，11 および 12 はそれぞれケース(a)〜 (c)での 左柱基部における軸力 $N$, 曲げモーメント $M$ およびせ ん断力 $S$ の応答である. 軸力応答の最大值はケース(b) の方がケース(a)の方より大きくなっている．曲げモー メントは全ケースにおいて，終局モーメントで頭打ちと なった応答になっている．軸力と曲げモーメントの関係 から曲げモーメントが負の時は作用軸力が減少し，正の 時は増加している.この曲げモーメントの正と負のピー ク值が異なるのは, 軸力変動に伴って中立軸が移動する ためである.

\section{5 コンクリートおよび鉄筋の応力}

図一13 および 14 はケース(a)におけるコンクリートお よび鉄筋の応力履歷である. 図一13 は左側柱の最外縁 $\left(\zeta_{i}=0\right)$ のコンクリート応力を示したもので，ひずみ $-\varepsilon_{c c}$ で圧壊した後, 圧縮応力が発生しなくなっている.

しかし最外縁以外のコンクリートは圧壊に至ることはな かったが，全断面において引張ひずみ $\alpha \varepsilon_{m}$ を大きく超 えていた. 図一14 に示寸主鉄筋の応力履歷において, 鉄筋が引張ひずみを受け残留ひずみを残しながら徐々に
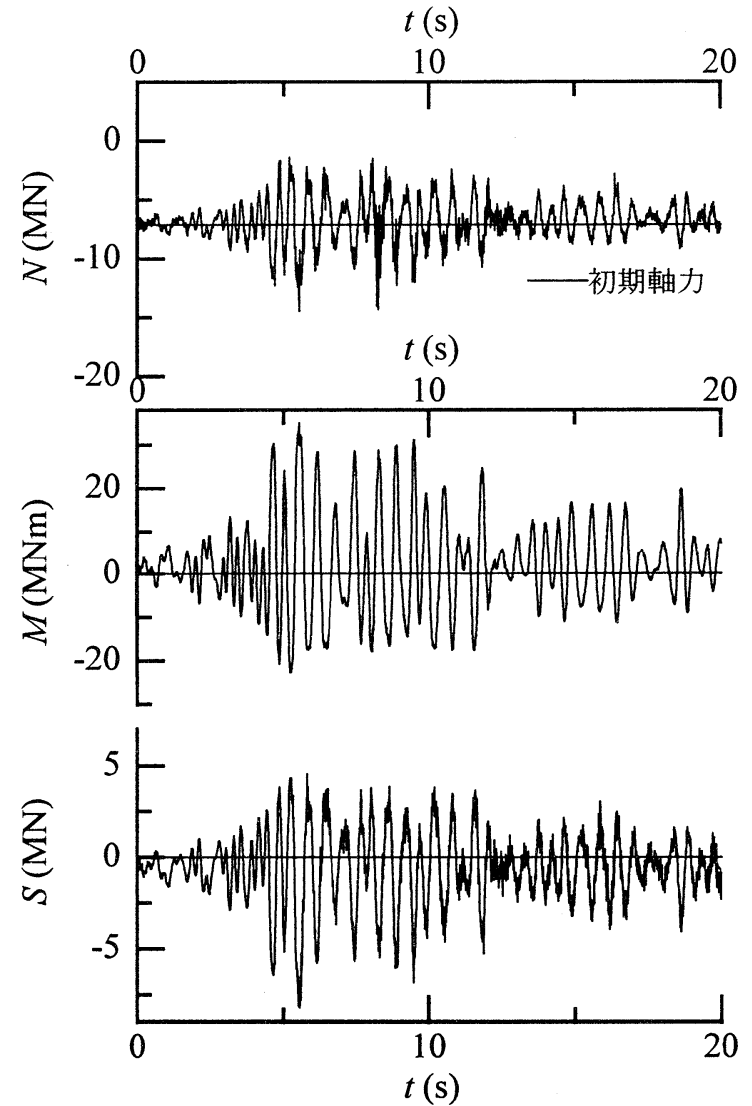

図-10 ケース(a), 左柱基部のおける断面力応答
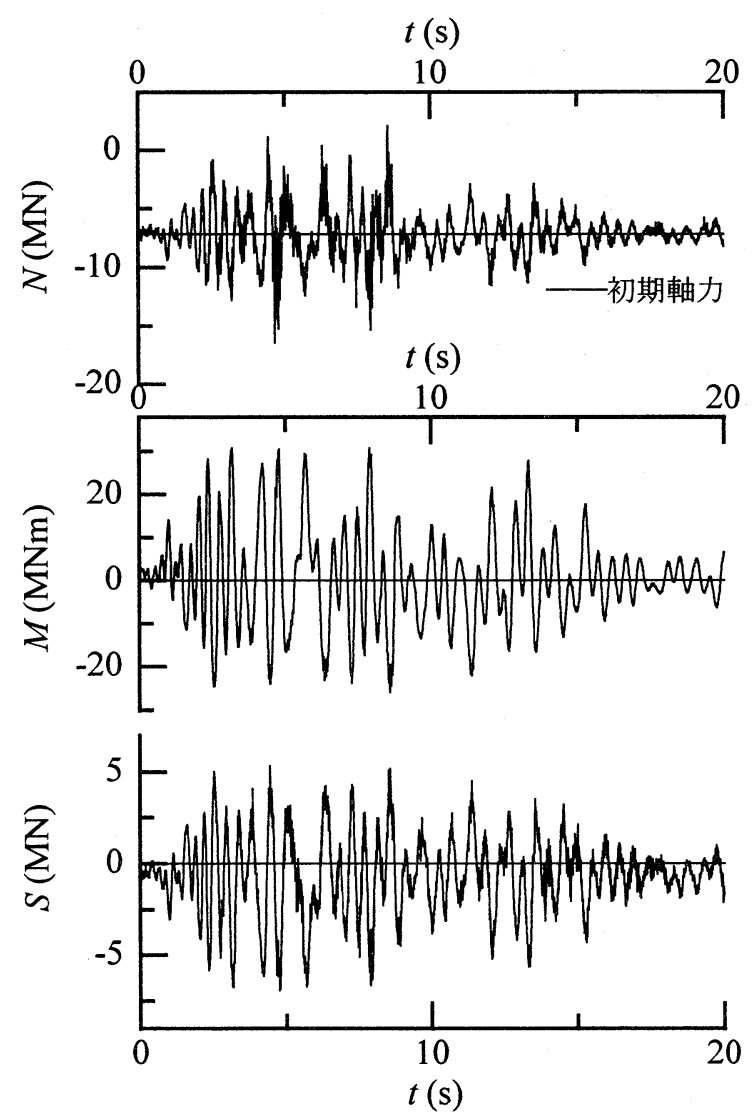

図-11 ケース(b), 左柱基部における断面力応答 


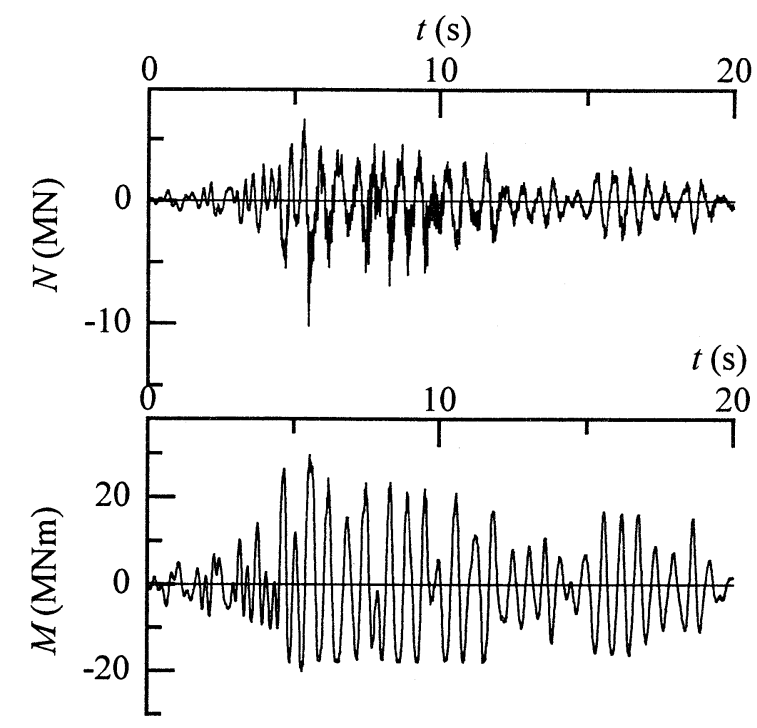

伸びているのがわかる. なお，図一13 および 14 のいず れにおいても 100 計算ステップ毎に 1 回出力したデータ のみをプロットしているので，実際の計算はより連続し たものであることを付記する.

\section{6 曲げモーメント履歴}

図一15〜20 はケース(a) 〜 (c)における左右柱基部 と, 梁両端部における曲げモーメント履歷である. ケー ス(a)では左柱基部の最大曲率の方が右柱より大きくな っている. 一方，ケース(b)では右柱基部の方が最大曲 率，残留曲率ともに大きくなっており，入力地震波によ る非線形応答の違いが生じている，(a)，(b)いずれのケ 一スも柱基部は塑性ヒンジ的な挙動を示し，ケース(a) は梁左端，ケース(b)は梁右端が塑性ヒンジになりつつ ある状況と思われる．その他に塑性ヒンジとなって崩壊 メカニズムを形成する可能性のある箇所として柱上端が 考えられるが,ここではほぼ線形的な履歷を示していた. また，ケース(c)においては軸引張の影響が顕著に現れ ており, 引張ひずみ $\alpha \varepsilon_{m}$ を超えてコンクリートの引張 応力が全くなくなった後, 主鉄筋と側面鉄筋が降伏, 除 荷を繰り返すことによる履歴が見られる.

$t$ (s)

図-12 ケース(c), 左柱基部における断面力応答

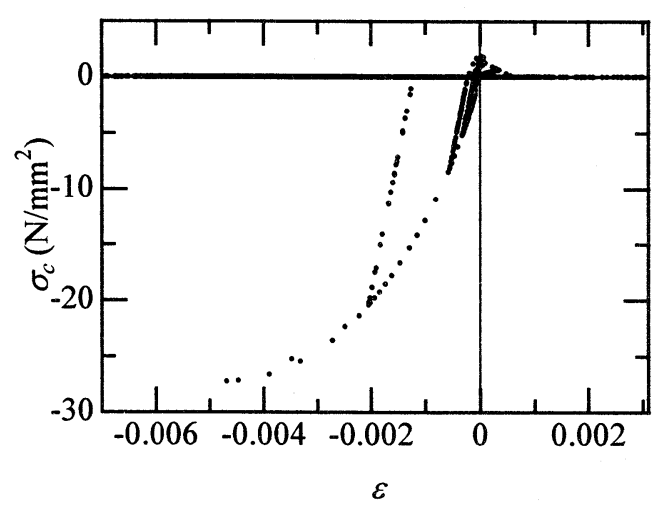

図-13 コンクリ一ト応力履歷（左杜基部）

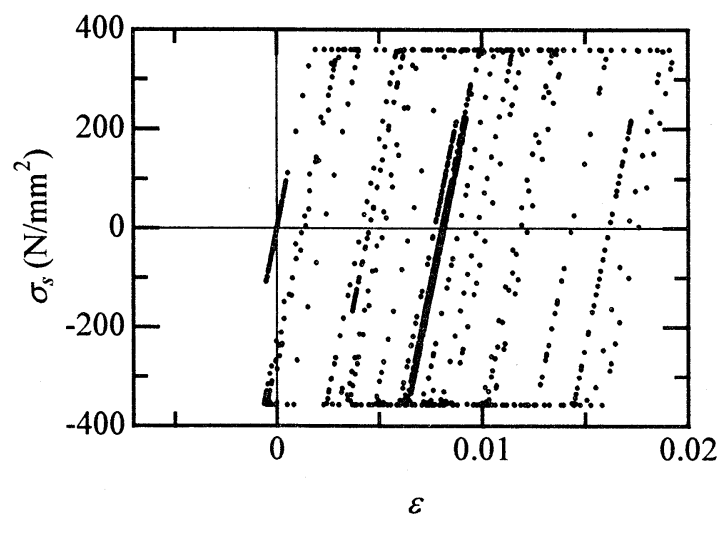

図-14 主鉄筋応力履歷（左側基部内側）

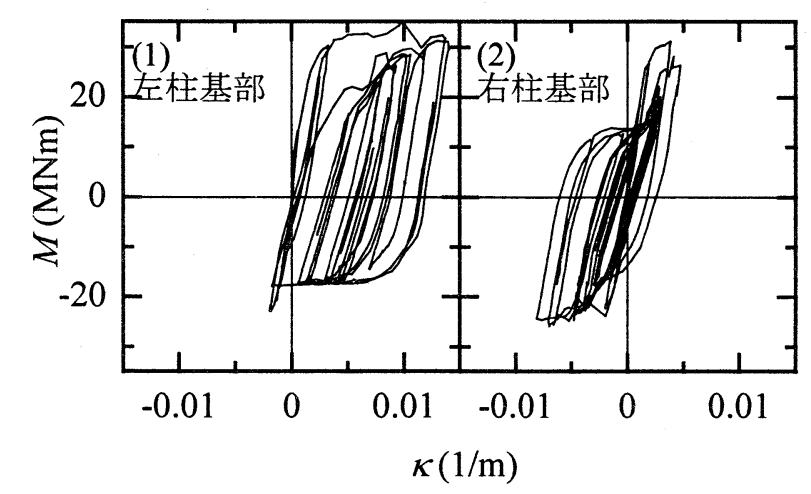

図ー16 ケース(a), 柱基部の曲げモーメント履歷 


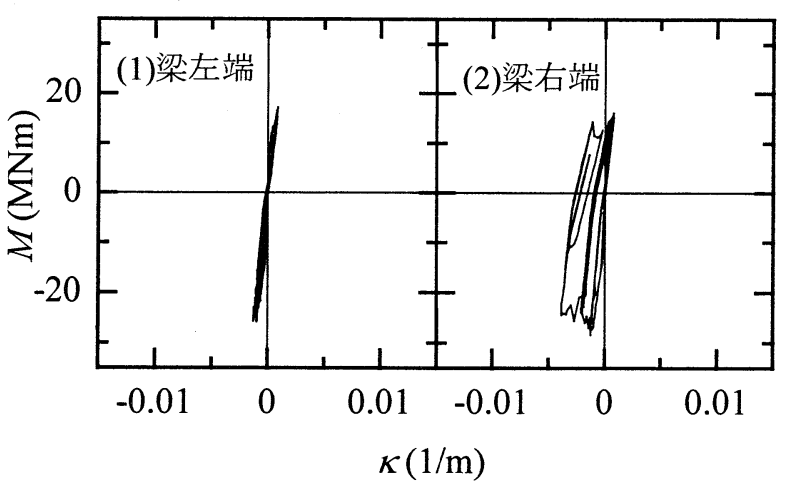

図-17 ケース(b), 梁端部の曲げモーメント履歷

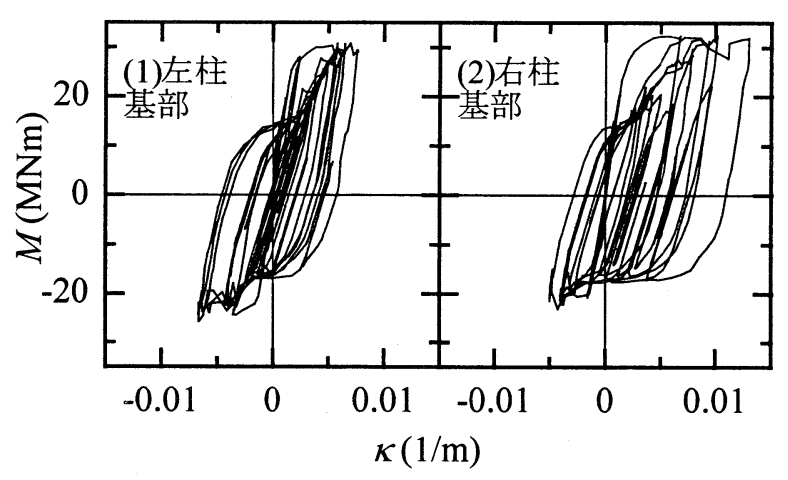

図-18 ケース(b), 柱基部の曲げモーメント履歴

\section{4. まとめ}

時間積分に陽解法である中心差分法を用い，断面力を 重心の変位にもとづいて算出されたひずみ $\delta, \kappa, \gamma$ の 関数としてファイバーモデルで表現することは，コンク リートおよび鉄筋などの材料構成関係を直接取り入れる ことが容易であり，時刻歴応答解析など莫大な計算ステ ップを必要とする数值解析において非常に適用性が高い. 既往の動的解析においては，軸力を一定としたうえで曲 げモーメントー曲率の関係を事前に規定していることが 多く, 時々刻々の軸力変動を考慮することが難しいが, 本法によれば，平面保持の仮定にしたがって軸力の変動 を常時計算に取り入れることができた. さらに，本解析 で用いた陽解法は弾性状態で発散することのないような 十分小さな時間刻みを用いることによって, コンクリー トおよび鉄筋の各ファイバーが降伏，除荷，圧壊での応 力状態の大きな変化に対しても安定した応答計算ができ た. なお, 解析 1 ケースに要した計算時間は EWS を使 用して約 10 分であった.

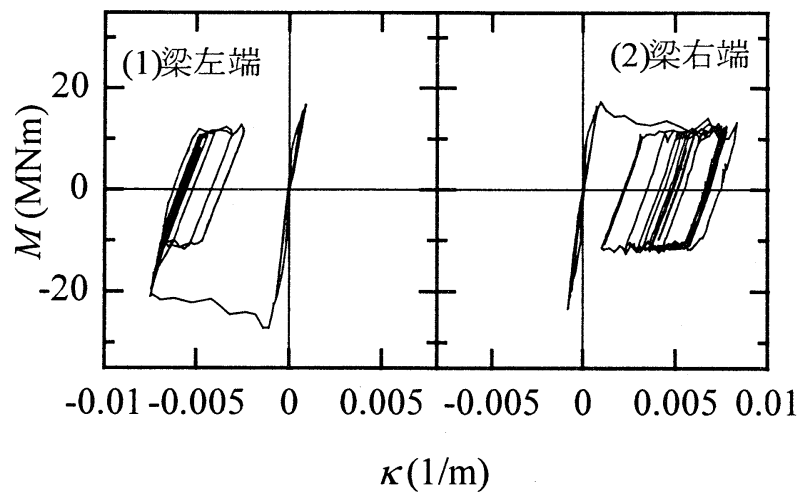

図-19 ケース(c), 梁端部の曲げモーメント履歴

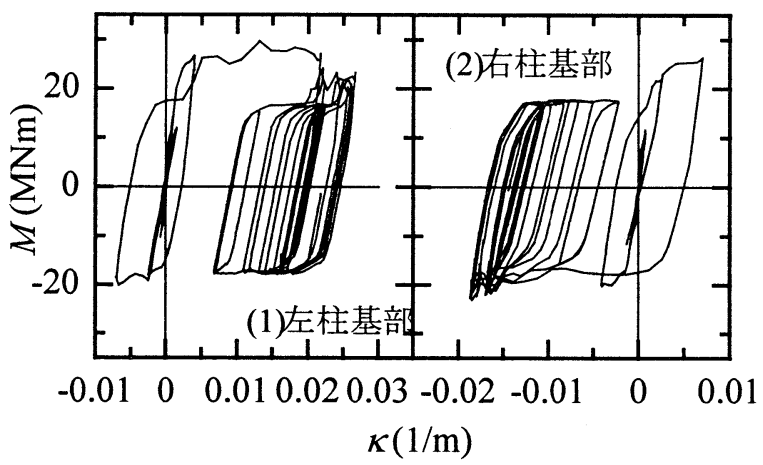

図一20 ケース(c)，柱基部の曲げモーメント履歷

\section{参考文献}

1）（社）日本道路協会 : 道路橋示方書 - 同解説 $\cdot V$ 而震 設計編, 1996.

2）園田佳巨，小林直行, 石川信隆, 佐藤紘志 : ひずみ 速度効果を考慮した P Cはり部材の動的曲げ耐力と 変形性能, 構造工学論文集, Vol. 38A, pp. 1455-1465, 1992.

3) 芳村学, 青山博之, 川村満 : 2 方向外力を受ける鉄筋 コンクリート構造物の解析一その $1 ; 2$ 軸曲げを受 ける RC 柱の解析，日本建築学会論文報告集，第 298 号, pp. 31-41, 1980.

4) Kawai, T. : Some consideration on the finite element method, International Journal for Numerical Methods in Engineering, Vol. 16, pp. 81-120, 1980.

5) 松浦幹佳, 島田功, 小林治俊, 園田恵一郎 : R C 橋 脚の地震応答解析に対する剛体バネモデルの適用,

構造工学論文集, Vol. 44A, pp. 1413-1422, 1998.

6) R. J. Cope: Non-linear Analysis of Reinforced Concrete Slabs, in Computational Modelling of Reinforced Concrete Structures (Ed. by E. Hilton and R. Owen), Pineridge Press, Swansea, U.K., pp. 3-43, 1986.

（1999 年 4 月 23 日受付） 